\title{
PENINGKATAN SELF CONFIDENCE MAHASISWA PRODI PRNDIDIKAN MATEMATIKA MELALUI MODEL PEMBELAJARAN KOOPERATIF TIPE JIGSAW DI STKIP BUDIDAYA
}

\author{
Lilis Saputri* \\ Program Studi Pendidikan Matematika STKIP Budidaya Binjai, Indonesia \\ E-mail :falinsyah16@gmail.com
}

\begin{abstract}
ABSTRAK
Penelitian ini bertujuan untuk 1). Untuk mengetahui peningkatan self confidence mahasiswa prodi pendidikan matematika melalui model pembelajaran kooperatif tipe Jigsaw. Jenis penelitian ini adalah eksperimen semu (quasi eksperimen) dengan desain Pretest-Posttest-control Group Desain. Pengujian data menggunakan uji N-Gain. Hasil penelitian menunjukan bahwa Berdasarkan hasil penelitian maka diperoleh kesimpulan sebagai berikut : peningkatan self confidence siswa yang diajarkan dengan pembelajaran kooperatif tipe jigsaw lebih baik daripada peningkatan self confidence pada siswa yang diajarkan dengan pembelajaran biasa.
\end{abstract}

Kata Kunci : Model pembelajaran kooperatif tipe Jigsaw dan Self Confidence. 


\section{PENDAHULUAN}

Prestasi belajar merupakan hal yang menjadi sorotan utama bagi kualitas dari pendidikan itu sendiri. Setiap peserta didik memiliki prestasi yang berbeda-beda tergantung pada kemampuan yang mereka miliki, biasanya digolongkan menjadi tiga yakni prestasi yang tinggi, sedang dan rendah. Dalam tingkat SD, SMP dan SMA prestasi belajar ditandai dengan nilai raport pada setiap tahun, sedangkan pada perguruan tinggi prestasi belajar ditandai dengan IPK (Indeks Prestasi Komulatif) yang merupakan akumulasi dari seluruh nilai pada setiap semester.

Setiap mahasiswa bersaing untuk memperoleh prestasi yang sesuai dengan ekspektasi yang telah mereka tentukan. Namun, tidak semua individu dapat memperoleh prestasi belajar yang baik, bahkan tidak jarang pula seorang individu demi memperoleh prestasi yang baik, dapat melakukan tindakan yang tidak diharapkan, misalnya saja memperoleh nilai yang baik dengan cara menyontek. Hal ini dapat dipengaruhi oleh beberapa hal, salah satu diantaranya adalah tingkat percaya diri yang merupakan aspek pribadi yang melekat pada diri individu itu sendiri.

Individu yang memiliki latar belakang yang mendukung akan memperoleh tingkat percaya diri yang tinggi sehingga mampu bersosialisasi dengan baik. Percaya diri atau self confidence adalah aspek kepribadian yang penting pada diri seseorang. Tanpa adanya kepercayaan diri maka akan banyak menimbulkan masalah pada diri seseorang. Kepercayaan diri merupakan atribut yang paling berharga pada diri seseorang dalam kehidupan bermasyarakat, karena dengan adanya kepercayaan diri, seseorang mampu mengaktualisasikan segala potensi yang ada di dalam dirinya. Sifat percaya diri ini juga dapat dipengaruhi oleh kemampuan dan keterampilan yang dimiliki.
Mahasiswa yang memiliki sifat percaya diri yang tinggi akan mudah berinteraksi dengan mahasiswa lainnya, mampu mengeluarkan pendapat tanpa ada keraguan dan menghargai pendapat orang lain, mampu bertindak dan berpikir postif dalam pengambilan keputusan, sebaliknya mahasiswa yang memiliki kepercayaan diri yang rendah akan sulit untuk berkomunikasi, berpendapat, dan akan merasa bahwa dirinya tidak dapat menyaingi mahasiswa yang lain.

Perbedaan tingkat percaya diri yang dimiliki individu tentu akan mempengaruhi perolehan prestasi belajar. Individu yang memiliki percaya diri yang tinggi akan memperoleh pretasi yang baik karena selalu beranggapan positif dan percaya terhadap kemampuan diri sendiri. Begitupun sebaliknya, individu yang memiliki percaya diri yang rendah akan memiliki prestasi belajar yang kurang memuaskan karena selalu beranggapan negatif dan tidak percaya akan kemampuan dan potensi yang dimilikinya.

Dari hasil lembaga kemahasiswaan di STKIP Budidaya dapat memberikan peran mahasiswa dalam meningkatkan interaksi sosialnya. Karena dalam sebuah organisasi banyak kegiatan atau diskusi yang dilakukan dimana semua anggota harus berpartisifasi di dalamnya, dari situlah mahasiswa biasa saling bertukar pikiran, menyampaikan gagasan atau mencari solusi dalam memecahkan masalah. Menurut Komara (2016), "semakin tinggi kepercayaan diri dan prestasi belajar maka perencanaan karir semakin tinggi dan sebaliknya apabila kepercayaan diri dan prestasi belajar rendah maka perencanaan karir akan semakin rendah". Setiap perubahan yang terjadi pada kepercayaan diri dan prestasi belajar akan berpengaruh pada terjadinya perencanaan karir pada siswa. Berdasarkan dokumentasi nilai mahasiswa Program Studi Pendidikan Pendidikan Matematika STKIP Budidaya, diketahui bahwa rata-rata nilai IP (Indeks Prestasi) dari seluruh mahasiswa hanya 
berada pada kategori memuaskan. Selain itu, masih banyak mahasiswa yang mungkin saja cenderung untuk menutup diri. Menutup diri merupakan salah satu ciri orang yang memiliki kepercayaan diri yang rendah, dimana mereka lebih cenderung untuk diam, kurang aktif, sulit berbicara di depan umum, ragu-ragu dalam mengeluarkan pendapat, dan masih banyak pula mahasiswa yang menyontek ketika ujian maupun pada saat mengerjakan tugas. Dengan rasa percaya diri yang rendah, maka seseorang akan kesulitan untuk mengambil keputusan jika dihadapkan pada suatu permasalahan dan akan selalu bergantung kepada orang lain.

Percaya diri terlihat pada saat mahasiswa presentasi di depan kelas dimana mahasiswa masih kurang percaya diri ketika menyampaikan presentasi dan berinteraksi dengan peserta presentasi. Mahasiswa juga cenderung malu ketika akan mengajukan pertanyaan kepada dosen jika mahasiswa merasa kurang jelas terhadap penjelasan dosen. Banyak mahasiswa juga masih merasa dirinya tidak yakin dengan kemampuan yang dimilikinya. Dapat dikatakan bahwa mahasiswa masih tidak percaya diri akan penampilan dan kemampuannya, dan tidak itu saja maraknya budaya mencontek di kalangan mahasiswa yang sulit dihilangankan sebagai bentuk dari rendahnya kepercayaan diri dari mahasiswa.

Berdasarkan hal tersebut, memotivasi peneliti untuk melakukan penelitian agar mengetahui Kepercayaan Diri (Self Confidence) Mahasiswa Prodi Prndidikan Matematika Melalui Model Pembelajaran Kooperatif Tipe Jigsaw di STKIP Budidaya.

\section{Model Pembelajaran Kooperatif Jigsaw}

Salah satu model pembelajaran yang diharapkan dapat mengembangkan kemampuan pemahaman konsep matematika siswa adalah model pembelajaran kooperatif tipe jigsaw. Jigsaw telah dikembangkan dan diuji coba oleh Elliot Aroson dan temanteman di Universitas Texas, dan diadopsi oleh
Slavin dan teman-teman di Universitas John Hopkins. Model pembelajaran kooperatif tipe jigsaw dapat membantu memberdayakan setiap siswa untuk lebih bertanggungjawab dalam belajar. Melalui model pembelajaran kooperatif tipe jigsaw kita dapat mengembangkan kemampuan siswa untuk menguji ide dan pemahamannya sendiri. Siswa dapat memecahkan masalah tanpa takut membuat kesalahan, karena keputusan yang dibuat adalah tanggungjawab kelompoknya.

Adapun sintak model pembelajaran kooperatif tipe jigsaw adalah sebagai berikut.

1. Materi pelajaran dibagi ke dalam beberapa bagian. Sebagai contoh suatu materi dibagi menjadi 4 bagian.

2. Siswa dibagi menjadi beberapa kelompok. Banyak kelompok adalah hasil bagi jumlah siswa dengan banyak bagian materi. Misalnya dalam kelas ada 20 siswa, maka banyak kelompok adalah 5, karena materinya 4 bagian. Selanjutnya kepada setiap anggota dalam satu kelompok diberikan satu bagian materi.

3. Anggota dari setiap kelompok yang mendapatkan materi yang sama membentuk kelompok. Kelompok ini disebut kelompok ahli (expert group). Banyaknya kelompok ahli ini sama dengan banyaknya bagian materi. Pada kelompok ahli inilah siswa melakukan diskusi untuk membahas materi yang menjadi tanggung jawabnya.

4. Setelah materi didiskusikan dan dibahas pada kelompok ahli, masing anggota kelompok ahli kembali ke kelompok asalnya (home teams) untuk mengajarkan kepada anggota kawan-kawannya. Karena ada 4 bagian materi, maka ada 4 orang yang mengajar secara bergantian.

5. Guru melakukan evaluasi secara individual mengenai bahan yang telah dipelajari.

6. Penutup, yaitu menutup pelajaran sebagaimana biasanya.

\section{Self Confidence}


Menurut Thantaway (dalam Prayitno) bahwa : Istilah percaya diri adalah kondisi mental atau psikologis diri seseorang yang memberi keyakinan kuat pada dirinya untuk berbuat atau melakukan sesuatu tindakan. Orang yang tidak percaya diri memiliki konsep diri negatif, kurang percaya pada kemampuannya, karena itu sering menutup diri'. Lebih lanjut menurut Rahmat bahwa kepercayaan diri dapat diartikan sebagai suatu kepercayaan terhadap diri sendiri yang dimiliki oleh setiap orang dalam kehidupannya serta bagaimana orang tersebut memandang dirinya secara utuh dengan mengacu pada konsep diri. Menurut Lauster (2003), ada beberapa aspek dari kepercayaan diri yakni sebagai berikut: (1) Keyakinan akan kemampuan diri yaitu sikap positif seseorang tentang dirinya bahwa dia mengerti sungguh-sungguh akan apa yang dilakukannya; (2) Optimis yaitu sikap positif seseorang yang selalu berpandangan baik dalam menghadapi segala hal tentang diri, harapan dan kemampuan; (3) Obyektif yaitu orang yang percaya diri memandang permasalahan atau segala; (4) sesuatu sesuai dengan kebenaran semestinya, bukan menurut kebenaran pribadi; (5) Bertanggung jawab yaitu kesediaan seseorang untuk menanggung segala sesuatu yang telah menjadi konsekuensinya; dan (6) Rasional yaitu analisa terhadap suatu masalah, suatu hal, sesuatu kejadian dengan menggunakan pemikiran yang diterima oleh akal dan sesuai dengan kenyataan.

\section{METODE PENELITIAN}

Jenis penelitian yang digunakan dalam penelitian ini adalah penelitian eksperimen semu atau quasi eksperimen. Dikatakan kuasi eksperimen karena subjek penelitian tidak diacak sepenuhnya. Subjek penelitian berada dalam kelas-kelas tertentu, sehingga penentuan kelas penelitianlah yang diacak. Bentuk deasain yang digunakan pada penelitian ini adalah Control Group Pre-test-Posttest, dengan pola sebagai berikut:

\section{Penelitian Control Group Pre-test-Post-test}

\begin{tabular}{llll}
\hline $\mathrm{E}$ & $\mathrm{O}_{1}$ & $\mathrm{X}$ & $\mathrm{O}_{2}$ \\
$\mathrm{~K}$ & $\mathrm{O}_{1}$ & & $\mathrm{O}_{2}$ \\
\hline
\end{tabular}

(Sumber : Arikunto, 2006)

Keterangan:

E : kelas eksperimen

$\mathrm{K}$ : kelas kontrol

$\mathrm{O}_{1}$ : Pretest Self Confidence

$\mathrm{O}_{2}$ : Posttest Self Confidence

$\mathrm{X}$ : Model pembelajaran kooperatif tipe jigsaw

Populasi penelitian ini adalah seluruh mahasiswa STKIP Budidaya. Sampel dalam penelitian ini mahasiswa prodi pendidikan matematika STKIP Budidaya.

\section{HASIL DAN PEMBAHASAN}

Berdasarkan penelitian yang telah dilakukan, diperoleh data kemampuan pemahaman konsep matematika siswa dari hasil pretest dan posttest. Kemudian dilakukan uji normalitas dan uji homogenitas data pretest dan posttest pada kelas eksperimen dan kelas kontrol.

Pengujian normalitas data dilakukan dengan uji lilliefors dengan ketentuan jika $L_{o}<L_{\text {tabel }}$ maka disimpulkan bahwa sebaran data berdistribusi normal dan demikian sebaliknya. Uji normalitas data pretest kelas eksperimen diperoleh $L_{o}(0-0,0381)<$ $L_{\text {tabel }}(0,15662)$. Dan untuk kelas kontrol diperoleh $\quad L_{o}(-0,0168)<L_{\text {tabel }}(0,15662)$. Data posttest kelas eksperimen diperoleh $L_{o}(0,00695)<L_{\text {tabel }}(0,15662)$. Dan untuk kelas kontrol diperoleh $L_{o}(0,0625)<$ $L_{\text {tabel }}(0,15662)$.

Untuk menguji homogenitas dari data yang diperoleh selama penelitian, digunakan uji Fisher. Untuk kriteria pengujian data sampel adalah homogen jika $F_{\text {hitung }}<F_{\text {tabel }}$ pada taraf nyata $\alpha=0,05$. Uji homogenitas pretest pada kemampuan pemahaman konsep kelas eksperimen dan kontrol diperoleh $F_{\text {hitung }}(0,9321)<F_{\text {tabel }}(1,8221)$ dan data 
posttest kemampuan pemahaman konsep kelas eksperimen dan kontrol diperoleh $F_{\text {hitung }}(0,6347)<F_{\text {tabel }}(1,8221)$.

Pengujian hipotesis pertama adalah untuk melihat peningkatan self confidence siswa. Hasil yang diperoleh adalah bahwa ngain pada kelas eksperimen 0,264 sedangkan pada kelas kontrol adalah 0,202 maka $\mathrm{H}_{\mathrm{a}}$ diterima bahwa self confidence siswa pada kelas eksperimen lebih baik dibandingkan pada kelas kontrol.

\section{KESIMPULAN}

Berdasarkan hasil penelitian maka diperoleh kesimpulan sebagai berikut : Peningkatan self confidence siswa yang diajarkan dengan pembelajaran kooperatif tipe jigsaw lebih baik daripada peningkatan self confidence pada siswa yang diajarkan dengan pembelajaran biasa.

\section{DAFTAR PUSTAKA}

Arikunto, Suharsimi. (2006). Prosedur Penelitian Suatu Pendekatan Praktik. Jakarta : PT. Rineka Cipta.

Dahar, R.W. (2006). Teori-teori Belajar \& Pembelajaran. Jakarta: Erlangga.

Departemen Pendidikan Nasional. (2007). Kamus Besar Bahasa Indonesia. Jakarta : Balai Pustaka.

Hamalik, Oemar. (2008). Kurikulum dan Pembelajaran. Jakarta : Bumi Aksara.

Hamdani. (2011). Strategi Belajar Mengajar. Bandung : Pustaka Setia.

Komara, I. B. (2016). Hubungan antara Kepercayaan Diri dengan Prestasi Belajar dan Perencanaan Karir Siswa. Jurnal PSIKOPEDAGOGIA 2016. Vol. 5, No. 1 ISSN : 2301-6167. Jakarta: Universitas Ahmad Dahlan.
Lauster, P. (2003). Tes Kepribadian (alih bahasa: D.H. Gulo). Jakarta: PT. Bumi Aksara.

Prayitno. (2013). Konseling Integritas. Padang: UNP.

. (2006). Perencanaan Belajar Mengajar. Bandung : Bumi Aksara.

\section{- (2005). Perencanaan Pengajaran Berdasarkan Pendekatan Sistem. Bandung : PT. Citra Aditya Bakti.}

Rahmat. (2016). Peningkatan Kemapuan Pemahamand dan Komunikasi Matematis Siswa Madrasah Aliyah Melalui Model Pembelajara Kooperatif Tipe Jigsaw. Sebuah penelitian di MAN Peisangan Bireuen. Aceh: Unsyiah.

Siti Mawaddah, Ratih Maryant. (2016). Kemampuan Pemahaman Konsep Matematis Siswa Smp Dalam Pembelajaran Menggunakan Model Penemuan Terbimbing (Discovery Learning). EDU-MAT Jurnal Pendidikan Matematika, Volume 4, Nomor 1, 76-85

Syahbana Ali. (2013). Peningkatan kemampuan pemahaman matematis mahasiswa melalui penerapan strategi metakognitif. Jurnal pendidikan matematika, Vol 03 no 02.

Trianto. (2011). Mendesain Model Pembelajaran Inovatif Progresif. Jakarta: Kencana. 